\title{
Commitment to Care for the Community and COVID-19: teaching-learning approach to medical education in primary health care in Brazil
}

\section{Compromisso de Cuidar da Comunidade e COVID-19: abordagem ensino- aprendizagem da educação médica na atenção básica à saúde no Brasil}

DOI: $10.46919 / \operatorname{archv1n5-018}$

Recebimento dos originais: 10/07/2020

Aceitação para publicação: 30/08/2020

\section{Bruno Bastos Godoi}

Discente do curso de Medicina da Universidade Federal dos Vales do Jequitinhonha e Mucuri (UFVJM)

Instituição: Universidade Federal dos Vales do Jequitinhonha e Mucuri (UFVJM)

Endereço: Faculdade de Medicina, Rodovia MGT 367 - Km 583, nº 5.000. Alto da Jacuba CEP 39100000. Diamantina, Minas Gerais, Brasil

E-mail: bastosgodoi@gmail.com

\section{Luiza Vilas Boas Freitas}

Discente do curso de Medicina da Universidade Federal dos Vales do Jequitinhonha e Mucuri (UFVJM) Instituição: Universidade Federal dos Vales do Jequitinhonha e Mucuri (UFVJM)

Endereço: Faculdade de Medicina, Rodovia MGT 367 - Km 583, nº 5.000. Alto da Jacuba CEP 39100000. Diamantina, Minas Gerais, Brasil

E-mail: luiza.vbf@gmail.com

\section{Delba Fonseca Santos}

Doutora em Saúde Coletiva pela Universidade Estadual de Campinas (UNICAMP)

Docente do curso de Medicina da Universidade Federal dos Vales do Jequitinhonha e Mucuri (UFVJM)

Instituição: Universidade Federal dos Vales do Jequitinhonha e Mucuri (UFVJM)

Endereço: Faculdade de Medicina, Rodovia MGT 367 - Km 583, nº 5.000. Alto da Jacuba CEP 39100000. Diamantina, Minas Gerais, Brasil

E-mail: delbafonseca@yahoo.com.br

\begin{abstract}
The major challenge of the COVID-19 pandemic to all countries has been to their healthcare systems and how to face it with excellence. Medical education can contribute in a short period so that the health system responds effectively to the current challenges imposed by the pandemic. Political implications identification and action are important to show that they can convert ideas into realities. In the middle of the COVID-19 pandemic, literacy in individual, community, and population health is more important than ever. As knowledge about COVID-19 grows rapidly, so does the opportunity to shape more effective interprofessional educational practices. During this pandemic, interprofessional collaborative teams are more crucial than ever in health promotion, mainly at the Primary Health Care.
\end{abstract}

Keywords: Education, Medical, Coronavirus Infections, Education, Medical, Undergraduate, Primary Health Care.

\section{RESUMO}

O maior desafio da pandemia COVID-19 para todos os países tem sido seus sistemas de saúde e como enfrentá-la com excelência. A educação médica pode contribuir em um curto espaço de tempo para que o 
sistema de saúde responda de forma eficaz aos desafios atuais impostos pela pandemia. A identificação e ação das implicações políticas são importantes para mostrar que podem converter ideias em realidades. No meio da pandemia COVID-19, a alfabetização na saúde individual, comunitária e populacional é mais importante do que nunca. À medida que o conhecimento sobre COVID-19 cresce rapidamente, também cresce a oportunidade de moldar práticas educacionais interprofissionais mais eficazes. Durante esta pandemia, as equipes colaborativas interprofissionais são mais cruciais do que nunca na promoção da saúde, principalmente na Atenção Básica.

Keywords: Educação Médica, Infecções por Coronavírus, Educação Médica, Graduação, Atenção primária à saúde.

\section{INTRODUCTION}

The coronavirus disease 2019 (COVID-19) pandemic is reaching on individuals, families, communities, and societies across the world. It has sent shock waves, generating uncertainty, fear, and questions about the role of the medical student during public health crises. The pandemic may serve as the greatest leveler of our time and teach us to recognize the fragility in all healthcare systems and is causing enormous changes in society and health care ${ }^{1}$.

Medical education can contribute in a short period so that the health system responds effectively to the current challenges imposed by the pandemic. Most medical schools across the world have started to rapidly transfer their curricula from face to face to online delivery using. Besides, medical students should spend the month in online training on infectious disease epidemiology, infectious disease control in highrisk settings, and response. ${ }^{2,3}$.

It is reported that time taken for the development of equivalent new knowledge was 50 years in 1950 which has reduced to 3.5 years in 2010 and is projected to be 73 days in $2030^{4}$. Medical schools have been working to transform pedagogy by eliminating/reducing lectures; using technology to replace/enhance anatomy and laboratories; implementing team-facilitated, active, and self-directed learning; and promoting individualized and interprofessional education 5,6 .

Medical education, today spans undergraduate, postgraduate, and the continuing professional development of established clinicians with a reputation for innovation in teaching and learning provision. This should be approached on the best evidence considering principles of Evidence-Based Medical Education (EBME) and using Competence-Based Medical Education (CBME) as a framework to convey the needed competencies ${ }^{7}$. The highlight at CBME is that the proximity between classroom education and service-based vocational training is a differential that could ensure dynamism, integration between disciplines, professions, and emphasizes the longitudinal and permanent knowledge building aspect ${ }^{8}$.

The major challenge of the COVID-19 pandemic to all countries has been to their healthcare systems and how to face it with excellence. This teaching and learning strategy are underpinned by the 
overarching to recognize the importance of teaching in primary care. Studies show that contextual learning or more meaningful learning for medical students can be enhanced by early exposure to community settings ${ }^{9,10}$. World Health Organization (WHO) specifically describes variations of activities of primary health care exposure for medical students and lessons learned from many countries to approach the health needs of the people ${ }^{11}$.

In Brazil, the National Curriculum Guidelines call for medical education curricula to be committed to a Unified Health System (Sistema Único de Saúde - SUS). In undergraduate education involves the development of a framework of collaboration mechanisms between different disciplines, preferably as early ${ }^{12}$. Primary Health Care (PHC) services are provided by the Family Health Strategy (FHC) through a privileged teaching-learning context for the understanding of the population's health needs and the student to experience a set of actions associated to care ${ }^{13}$.

This study has explored the considerations and the influencing teaching-learning in PHC for medical education to approach COVID-19.

\section{IMPLEMENTING COMPETENCY-BASED MEDICAL EDUCATION IN PRIMARY HEALTH CARE IN THE FACE TO THE COVID-19}

Lifelong medical students learning is a process involving assessing practice. Competency-based medical education is an outcome-based approach to the design, implementation, assessment, and evaluation of an educational program using an organized framework of competencies, which ultimately may lead to better care for patients ${ }^{8}$. Given this, it can apply this knowledge and skills into practice and also consolidate competencies ${ }^{14}$.

Political implications identification and action are important to show that they can convert ideas into realities. In the middle of the COVID-19 pandemic, literacy in individual, community and population health is more important than ever ${ }^{15-19}$. The organization of the effective health system for COVID-19 involves organizational health literacy in PHC reflecting a growing trend to consider health literacy at different levels. Moreover, Sentell et al. ${ }^{20}$ shows, in an editorial, across the levels of the socioecological model: individual (prevention, chronic care); interpersonal (social networks); organizational (health systems, workplaces, schools), larger community (tailoring for culture and context); and public policy. The authors also, consider a strategic perspective to achieve education for health literacy and equity examples from innovative practice in Canada across the lifespan.

The FHS is uniquely positioned to improve the health of patients and defend equity in health and the social well-being in response to the pandemic by equipping doctors with tools and resources to face the inequities. With a team together with the patient, an assessment, diagnosis, intervention, goal-setting, 
and the creation of a care plan are carried out. The patient, their family, and caregivers are involved in any discussions about their condition, prognosis, and care plan ${ }^{21}$.

Cooperation and relationship in the context of the organization of PHC services are a learning experience in the face of the COVID-19 pandemic. The PHC is essential to the effectiveness, fairness, rationality of care, and FHS carries this dual nature: the clinical care and health promotion/disease prevention ${ }^{22}$. Organizational promotion in the PHC is fundamental so that it can influence personal health behaviors, family relationships, organizational actions, state policy, mortality statistics, and decision-making.

Medical students should help ensure the implementation of critical preventive policies and join teams that swiftly and aggressively respond to coronavirus infection that occurs. Despite this, the training should go beyond the search for diagnosis and intervention in the illness process and adapt to the health needs of people and populations, sectoral management and social control in health, adjusting the development of people's autonomy to the condition of influence in healthcare policy formulation ${ }^{23}$. Evermore critical is the concern for health equity before the COVID-19 pandemic. The most profound consequences of the decision made in this health crisis are expected to fall hardest on the most disadvantaged populations ${ }^{24,25}$.

\section{LIFELONG MEDICAL STUDENTS LEARNING IN PRACTICE: INTERPROFESSIONAL EXPERIENCES AND EMPOWERING COMMUNITIES}

As knowledge about COVID-19 grows rapidly, so does the opportunity to shape more effective interprofessional educational practices. Centering transformation in academic primary care practices interprofessional creates an explicit link between clinical and educational redesign. Interprofessional education provides learners with opportunities to learn together with other professions to develop these attributes and skills, required for working collaboratively, and hence respond to needs especially those of community ${ }^{26}$. Taking advantage of these advances requires integrating insights across multiple fields from the doctor, biological, nurse, psychology, sociology, developmental, and learning sciences and connecting them to the knowledge of successful approaches that are emerging in education.

The Coronavirus causes cold-like symptoms, which can include a fever, coughing, and respiratory problems. In severe cases, people are hospitalized and appears to pose a particular risk for elderly people and those with pre-existing illnesses ${ }^{27}$. Slowing the transmission of COVID-19 and protecting communities, and this requires everyone adopting individual protection measures such as washing hands, avoiding touching their face, practicing good respiratory etiquette ${ }^{28}$. 
The primary care engages a diverse and rich range of professionals, organizations, and sectors. The WHO, in its proposed 'Five Star Doctor', emphasizes the need for a good communicator to be one of the essential competencies of graduating students ${ }^{29}$. While all of these have particular roles, knowledge, and skills, there is recognition of the need for professionals within primary care to better collaborate ${ }^{30,31}$.

During this pandemic, interprofessional collaborative teams are more crucial than ever in health promotion. Reflecting on this situation, Van den Broucke ${ }^{32}$, remind that health promotion can be more important than ever in this crisis moment, community engagement can make a substantial difference in health outcomes and that health promotion researchers and practitioners develop a keen interest in infectious diseases ${ }^{32}$.

Yet, at a time like this, creative models and effective collaborative practice in community-based care and the PHC need to be encouraged to ensure the education of health professionals in the face of health promotion for COVID-19. In a team, identify and define goals, and assume joint responsibility for actions to accomplish the goals. The WHO and others have repeatedly stressed the need for interprofessional education and practice as a way to not only improve the quality of care for patients, families, and communities but also for global health populations ${ }^{33}$.

In Brazil, PHS and teaching-service integration understood through the combined work of students, teachers, and workers in a practice setting has as its goals excellency in professional training and quality of the work in health ${ }^{34}$. This integration must take on common meanings and the resulting experiences must produce a gain for both institutions in the face of the COVID19 pandemic, which implies alignment of needs and potentialities.

This results in health promotion, the most essential component of any medical professional and team PHS. Reflecting on medical education, in Brazil, medical schools, since 2014, are performing curricular changes. The article by Peixoto et al. ${ }^{35}$, gives information on the Teaching, Service and Community Integration Practices (PIESC), it includes the development of medical education and delineates practices with communities, families, and people based on their vulnerabilities and care and the FHS. Considers which aspect of PIESC work presents new perspectives and potentialities based on strengthening the professionals and on expanding the interdisciplinary work ${ }^{35}$.

Since the COVID-19 establishment worldwide as a pandemic there have been plenty of changes in all social fields, mainly on health services. Moreover, this is a much different experienced situation in the past hundred years when talking about infectious diseases. Furthermore, this global scenario directly implies in medical education and other health graduation courses (as nursing, physiotherapist, dentistry, and pharmaceutics) due to limitation of practice actuation and also the shortage of individual protection equipment. 
Thereby, it is important to enhance the practical knowledge of medical students to feel more capable to assess patients with infectious diseases with all self-protection. Moreover, develop quality medical education and delineate practices involving all population fields (socioeconomic, health, among others).

\section{REFERENCES}

1. Greenhalgh T, Koh GCH, Car J. Covid-19: A remote assessment in primary care. BMJ. 2020;368. doi:10.1136/bmj.m1182

2. McKimm J, Gibbs T, Bishop J, Jones P. Health Professions' Educators' Adaptation to Rapidly Changing Circumstances: The Ottawa 2020 Conference Experience. MedEdPublish. 2020;9(1). doi:10.15694/mep.2020.000047.1

3. Goh P-S, Sandars J. A vision of the use of technology in medical education after the COVID-19 pandemic. MedEdPublish. 2020;9(1). doi:10.15694/mep.2020.000049.1

4. Densen P. Challenges and opportunities facing medical education. Trans Am Clin Climatol Assoc. 2011;122:48-58.

5. Skochelak SE, Stack SJ. Creating the Medical Schools of the Future. Acad Med. 2017;92(1):16-19. doi:10.1097/ACM.0000000000001160

6. Irby DM, Cooke M, O'Brien BC. Calls for reform of medical education by the Carnegie Foundation for the Advancement of teaching: 1910 and 2010. Acad Med. 2010;85(2):220-227. doi:10.1097/ACM.0b013e3181c88449

7. Francischetti I, Holzhausen Y, Peters H. The time has come for brazil: Translating competence based medical education into practice by entrustable professional activities (epas). Interface Commun Heal Educ. 2020;24. doi:10.1590/Interface.190455

8. Frank JR, Snell LS, Cate O Ten, et al. Competency-based medical education: Theory to practice. Med Teach. 2010;32(8):638-645. doi:10.3109/0142159X.2010.501190

9. Dolmans DHJM, Wolfhagen IHAP, Heineman E, Scherpbier AJJA. Factors adversely affecting student learning in the clinical learning environment: A student perspective. Educ Heal Chang Learn Pract. 2008;21(3):32.

10. Dornan T, Littlewood S, Margolis SA, Scherpbier A, Spencer J, Ypinazar V. How can experience in clinical and community settings contribute to early medical education? A BEME systematic review. Med Teach. 2006;28(1):3-18. doi:10.1080/01421590500410971

11. Talaat W LZ. Community Based Education in Health Professions: Global Perspectives. Cairo: WHO Regional Office for the Eastern Mediterranean.; 2014.

12. Zarpelon LFB, Terencio ML, Batista NA. Education-service integration in the context of brazilian medical schools: An integrative review. Cienc e Saude Coletiva. 2018;23(12):4241-4248. doi:10.1590/1413-812320182312.32132016 
13. Demarzo MMP, Almeida RCC de, Marins JJN, et al. Diretrizes para o ensino na atenção primária à saúde na graduação em medicina. Rev Bras Educ Med. 2012;36(1):143-148.

14. Merkur S, Mladovsky P, Mossialos E, Mckee M. Do Lifelong Learning and Revalidation Ensure That Physicians Are Fit to Practise? Copenhagen: World Health Organization; 2008.

15. Saboga-Nunes L, Levin-Zamir, D, Bittlingmayer U, Contu P, et al. A Health Promotion Focus on COVID-19: Keep the Trojan Horse out of Our Health Systems. Promote Health for ALL in Times of Crisis and Beyond!; 2020.

16. Okan, O., Sørensen, K. and Messer M. COVID-19: a guide to good practice on keeping people well informed. The Conversation.

17. Paakkari L, Okan O. COVID-19: health literacy is an underestimated problem. Lancet Public Heal. 2020;5(5):e249-e250. doi:10.1016/S2468-2667(20)30086-4

18. Sørensen K. Covid-19: Digital Health Literacy Is A Key To Saving Time, Costs And Lives ICT\&health.

19. Abel T MD. Critical health literacy and the COVID-19 crisis. Heal Promot Int Int. 2020:1-2.

20. Sentell T, Vamos S, Okan O. Interdisciplinary Perspectives on Health Literacy Research Around the World: More Important Than Ever in a Time of COVID-19. Int J Environ Res Public Health. 2020;17(9):3010. doi:10.3390/ijerph17093010

21. Macinko J, Harris MJ. Brazil's family health strategy - Delivering community-based primary care in a universal health system. $N$ Engl $J$ Med. 2015;372(23):2177-2181. doi:10.1056/NEJMp1501140

22. NORMAN, Armando Henrique; TESSER CD. Access to healthcare in the Family Health Strategy: balance between same day access and prevention/health promotion. Saude soc. 2015;24(1):165179.

23. Ceccim RB, Feuerwerker LCM. O quadrilátero da formação para a área da saúde: ensino, gestão, atenção e controle social. Physis Rev Saúde Coletiva. 2004;14(1):41-65. doi:10.1590/s010373312004000100004

24. Fisher, M.; Bubola E. As Coronavirus Deepens Inequality, Inequality Worsens Its Spread - The New York Times. The New York Times.

25. Tharoor I. Coronavirus could hit the world's most vulnerable people hardest - The Washington Post. The Washington Post.

26. Reeves S, Xyrichis A, Zwarenstein M. Teamwork, collaboration, coordination, and networking: Why we need to distinguish between different types of interprofessional practice. J Interprof Care. 2018;32(1):1-3. doi:10.1080/13561820.2017.1400150

27. Guan W, Ni Z, Hu Y, et al. Clinical Characteristics of Coronavirus Disease 2019 in China. N Engl J Med. 2020;382(18):1708-1720. doi:10.1056/NEJMoa2002032

28. WHO. COVID-19 Strategy Update. Geneva, Switzerland; 2020.

29. Boelen C. THE FIVE-STAR DOCTOR: An asset to health care reform? World Health Organization. 
30. Samuelson M, Tedeschi P, Aarendonk D DLCC and G, P. Improving interprofessional collaboration in primary care: position paper of the European Forum for Primary Care. Qual Prim Care. 2012;20:303-312.

31. Donnelly C, Ashcroft R, Mofina A, Bobbette N, Mulder C. Measuring the performance of interprofessional primary health care teams: understanding the teams perspective. Prim Health Care Res Dev. 2019;20:e125. doi:10.1017/S1463423619000409

32. Broucke S Van den. Why health promotion matters to the COVID-19 pandemic, and vice versa. Health Promot Int. 2020;16(daaa042):1-6.

33. WHO. Framework for Action on Interprofessional Education \& Collaborative Practice Health Professions Networks Nursing \& Midwifery Human Resources for Health. Geneva, Switzerland; 2010.

34. Albuquerque VS et al. A integração ensino-serviço no contexto dos processos de mudança na formação superior dos profissionais da saúde. Rev Bras Educ Med. 2008;32(3):356-362.

35. Peixoto MT, de Jesus WLA, de Carvalho RC, Assis MMA. Medical education in primary healthcare: A multiple-approach experience to teaching, service and community integration practices. Interface Commun Heal Educ. 2019;23. doi:10.1590/Interface.170794 